\title{
Palaeoenvironmental interpretation of echinoderm assemblages from Bathonian ore-bearing clays at Gnaszyn (Kraków-Silesia Homocline, Poland)
}

\author{
ANDRZEJ BOCZAROWSKI \\ Faculty of Earth Sciences, University of Silesia, Będzińska 60, PL-41-200 Sosnowiec, Poland. \\ E-mail: a.boczarowski@chello.pl
}

\begin{abstract}
:
Boczarowski A. 2012. Palaeoenvironmental interpretation of echinoderm assemblages from Bathonian ore-bearing clays at Gnaszyn (Kraków-Silesia Homocline, Poland). Acta Geologica Polonica, 62 (3), 351-366. Warszawa.

This paper presents the results of an investigation into the variability of echinoderm assemblages from Bathonian ore-bearing clays from Gnaszyn. Remains of Crinoidea, Asteroidea, Ophiuroidea, Echinoidea, and Holothuroidea have been studied from 38 rock samples. The most common echinoderms represented are the crinoids Balanocrinus berchteni and Chariocrinus andreae and a few species of the holothurian genera Priscopedatus, Calclamna, Staurocaudina, Eocaudina, Achistrum, Theelia and Hemisphaeranthos. The echinoderms from Gnaszyn show various life strategies: benthic or epibenthic forms, sessile sestonophages (Crinoidea), motile macrophages (Asteroidea) and detritivores (Asteroidea, Ophiuroidea, Echinoidea), infaunal and epifaunal detritus feeders, sediment feeders or rake-feeders (Holothuroidea). Their presence suggests well oxygenated and presumably relatively cold bottom marine waters. The parts of the Gnaszyn section around concretion horizons and characterized by the ubiquitous occurrence of the holothurian Theelia and echinoids were deposited during phases of optimal living conditions with sufficient influx of plant detritus and good oxygenation of the sea bottom. These parts commonly host echinoderm associations dominated by crinoid remains, which occasionally are still articulated (or disarticulated but remaining intact) - this points to a quiet environment with normal oxygenation of the bottom waters but anaerobic/dysaerobic conditions in the sediment.
\end{abstract}

Key words: Palaeoenvironment; Middle Jurassic; Bathonian; Echinoderms; Ore-bearing clays; Poland.

\section{INTRODUCTION}

The echinoderms from the Middle Jurassic orebearing clays of Poland have been a subject of numerous scientific contributions. Early papers (Laube 1867; Rehbinder 1913; Różycki 1953) gave only general reports on their presence. Later on, Dayczak-Calikowska (1980) provided a list of all hitherto identi- fied crinoids from the epicontinental Polish Basin. More recently, the crinoids were studied by Salamon and Zatoń (2006, 2007) and Salamon (2008). Górka and Łuszczewska (1969) described numerous Bajocian and Bathonian holothurians from the Częstochowa-Zawiercie area, while Jesionek-Szymańska $(1963,1980)$ studied echinoids from the Middle Jurassic of the Kraków-Częstochowa region. 
Boczarowski (in Gedl et al. 2003, 2004; Boczarowski 2005a) published preliminary results on the palaeoecological importance of the echinoderms from Gnaszyn. He described numerous echinoid pedicellariae from the orebearing clays of the Częstochowa area, focusing on their importance in defence strategy. The analysis of holothurian elements from the same area revealed the taphonomic processes during the early stages of their decomposition under anaerobic conditions (Boczarowski 2005a). Echinoderms from Gnaszyn were used to discuss some aspects of palaeoenvironmental reconstructions (Zatoń et al. 2007a, b). Perfectly preserved calcite crinoid ossicles were used in geochemical and micro/nannos- tructural (Stolarski et al. 2009) and palaeontological studies (Salamon and Zatoń 2007).

The present paper documents the echinoderms from Gnaszyn (Text-figs 1, 2), with the aim of reconstructing the environment in the Bathonian sea of the area. Echinoderms, and especially the Holothuroidea, are usually strongly facies-dependent, being good bioindicators. Diverse echinoderms indicate a fully marine environment with normal salinity (albeit some of them may tolerate salinities ranging from 7.7 to 60 $\%$; see e.g. Thomas 1961; Price 2007). Moreover, oxygen content and substratum type can be deduced based on echinoderm remains.

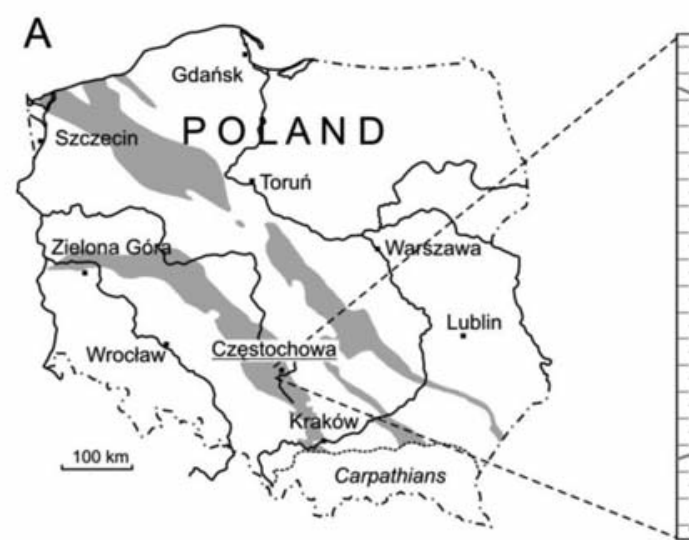

- Jurassic strata (exposed or below the Cainozoic cover)

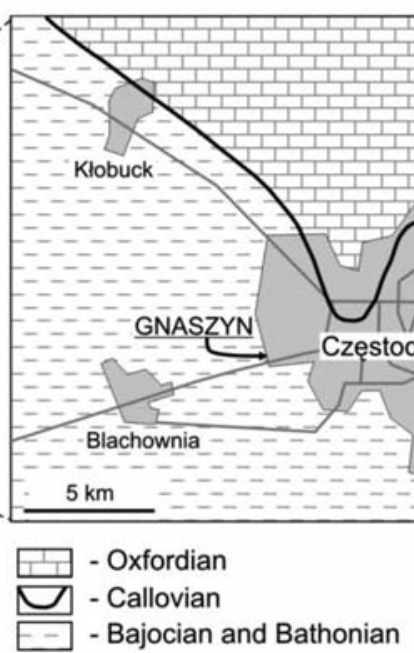

B

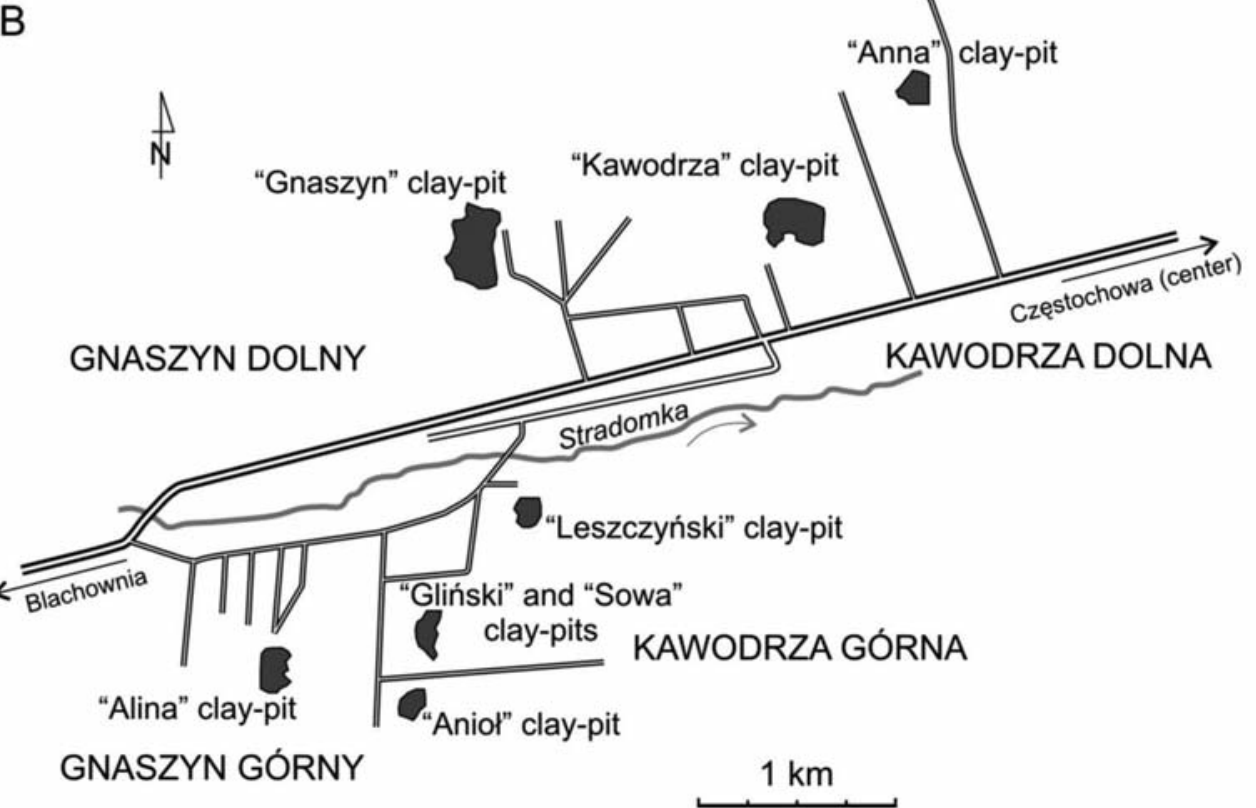


ECHINODERMS FROM MIDDLE JURASSIC ORE-BEARING CLAYS

\section{MATERIAL AND METHODS}

The material studied comes from a set of 38 samples of Gedl and Kaim (2012, this issue) from the Gnaszyn ore-bearing clays succession (Text-fig. 2). Additionally, more than 100 rock samples from the Gnaszyn brickyard were collected by the author, during 1998-2006. The sections studied are of Middle-Late Bathonian age (Subcontractus-Retrocostatum zones; see Matyja and Wierzbowski 2006). Ore-bearing clays from Gnaszyn represent monotonous sediments (Text-fig. 2). The samples were collected from homogeneous parts of the succession, as well as from those parts where some changes in lithology appear, particularly where there is macro- scopically visible enrichment in fossil detritus. The latter include samples with concentrations of mollusc shells and articulated crinoid stems. Some samples were taken from horizons rich in fossil wood; and also from horizons containing siderite concretions. In such cases, samples were taken from the top, bottom and from the middle parts of those horizons (Text-fig. 2).

The samples were softened and washed in hot water, then macerated by the method developed by Boczarowski (2001), following hot peptisation or shock oxidation in $\mathrm{H}_{2} \mathrm{O}_{2}$. The latter method was applied only to samples containing small amounts of pyrite - decomposition of larger amounts of this mineral leads to the formation of sulphuric acid, which

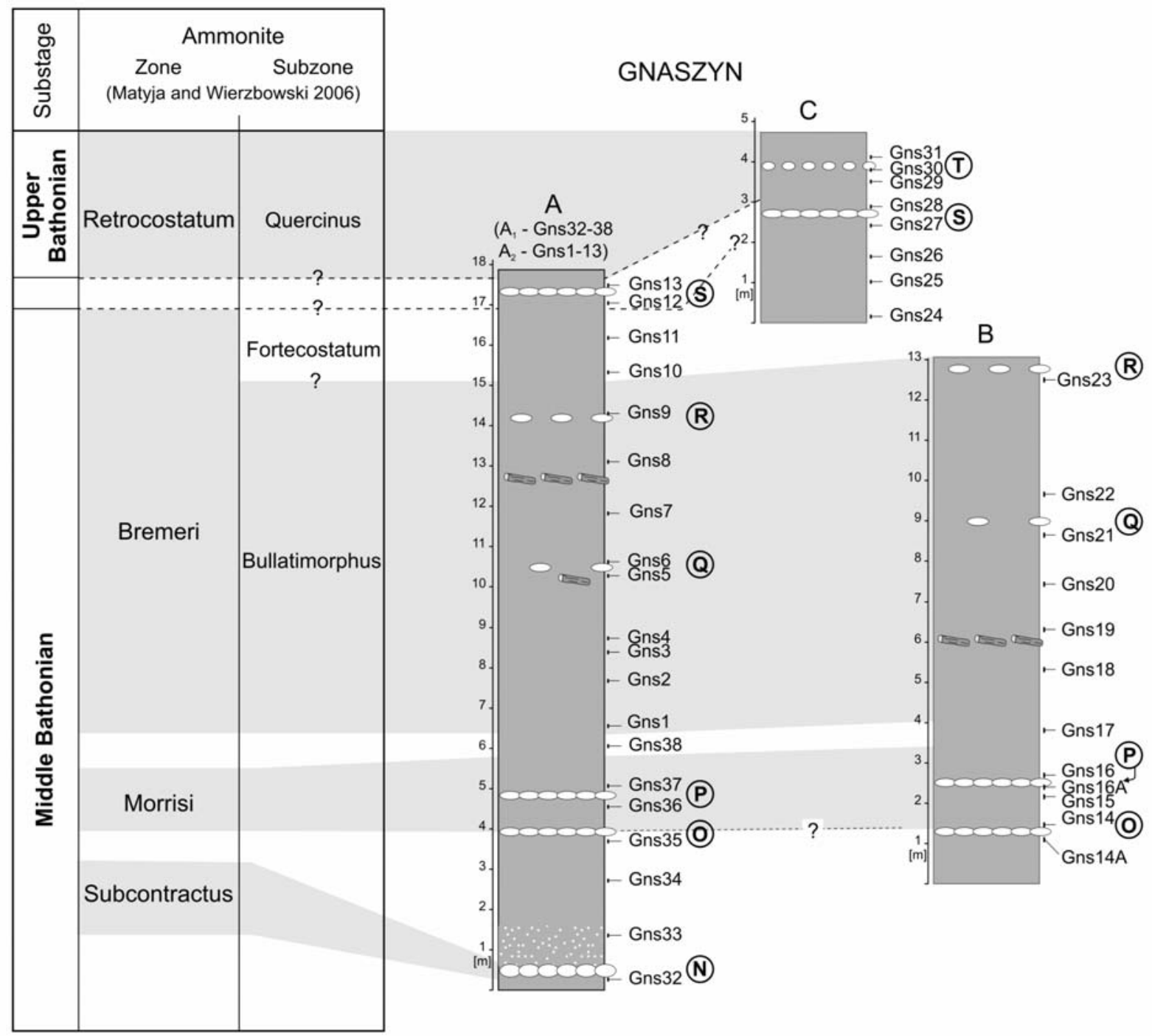

$\leftarrow$ Gns32 - sample location $\quad 000000$ - siderite concretion level

(N) - abbreviation of concretion level

Text-fig. 2. Lithological logs of the Gnaszyn sections with sample positions indicated (by P. Gedl, from Gedl and Kaim 2012) 
would dissolve delicate calcite micro-remains. The macerated samples were separated into three fractions using calibrated sieves: coarse $\phi>1.3 \mathrm{~mm}$, medium $1.3 \mathrm{~mm} \leq \phi>0.3 \mathrm{~mm}$, and fine $0.3 \mathrm{~mm} \leq \phi>0.02 \mathrm{~mm}$. The coarse fraction contained only crinoid columnals, interambulacral echinoid test plates and larger asteroid skeletal elements; the other fractions contained all other echinoderm remains but holothurian sclerites occurred only in the fine fraction.

Echinoderm scleritome usually consists of thousands to millions of sclerites. Exact count of individual numbers is therefore impossible. A good approximation is possible only when there are few skeletal elements in a single individual. For example in isocrinid crinoids there are only five basal and five radial plates, in asteroids only five terminal plates (in starfish with five arms), ophiuroids have ten oral plates, echinoids ten demipyramids (in regular echinoids) while holothurians have five radial plates in a calcareous ring.

\section{RESULTS}

The echinoderm skeletons are composed of numerous different elements, which usually disaggregate after the death of the animal. Echinoderm remains occur throughout the whole Gnaszyn succession and are almost exclusively disarticulated. The proportions of particular echinoderm groups are shown in Text-fig. 3. Crinoid scleritomes consist of calyx elements (basals), arms (axillary plates, brachials and pinnulae) and numerous stem elements (columnals and cirrals; Text-figs 4, 5). Sea stars (Asteroidea) are represented by arm plates (ambulacral plates, adambulacral plates, marginal plates and terminal plates) and paxillae (Text-fig. 6N-P). Ophiuroids are represented by numerous arm plates (vertebra; lateral, ventral and dorsal plates), oral plates, genital plates, spines, hooks and minor dermal skeletal ossicles (Text-fig. 6A-M). Echinoids are represented by ambulacral and interambulacral plates, apical plates, elements of the Aristotle's lantern (mainly demipyramids and teeth), spines of diverse morphology and globiferous and ophiocephalous pedicellariae (Text-fig. 7). Holothurians are represented by skin sclerites and calcareous ring elements (Text-figs 8, 9).

Crinoidea (37.5\%, 4520 ossicles). Analysis of the frequency of echinoderm remains shows that crinoid ossicles constitute the main part of the entire echinoderm sclerite assemblage in Gnaszyn (Text-fig. 3). There are samples where crinoids dominate in percentages, or are even the only group of echinoderms present, albeit their absolute number is low (samples Gns24, Gns27, Gns29). As expected, the largest variation of echinoderm elements coincides with the largest number of specimens, in sample Gns13. The numbers of crinoid ossicles vary from 0 (samples Gns16 and Gns19) to 828 (Gns13), 119 specimens per $1 \mathrm{~kg}$ on average (Text-fig. 3). Nevertheless, the numbers of elements given do not reflect the actual numbers of individuals and the counts are provided as an estimation of their abundance. As the crinoids in Gnaszyn are represented mostly by two genera (Chariocrinus and Balanacrinus), characterized by a long stem composed of hundreds to thousands of columnals, the estimations of the numbers of living animals they represent based solely on the whole number of specimens is impractical. The actual numbers of individuals might be assessed nevertheless by counting the number of basal plates which always occur in a number of five in a crinoid calyx. It should be noted, however, that calyx elements are excessively rare in the Gnaszyn section.

Asteroidea (4.5\%, 540 ossicles). The number of asteroid remains varies from sample to sample. This may indicate that the sample has been collected from a place where a skeleton of an asteroid disarticulated or that the sample contains regurgitate of an asteroid predator (Zatoń et al. 2007a, b). Asteroid ossicles are generally uncommon in Gnaszyn and absent from many samples (Gns1-3, Gns8, Gns11-12, Gns14, Gns19-20, Gns22, Gns24, Gns27-30). The absence of asteroids is especially pronounced in the bottom part of section A (Gns32-35; Text-figs 2, 3) and around concretionary horizon $\mathrm{T}$ in section $\mathrm{B}$ (Gns1-3). The highest number of specimens (69) was found in sample Gns13; also rich in asteroids are samples Gns5 and Gns9 (57 and 50 specimens respectively). On average, there are 14 specimens of asteroid ossicles in a $1 \mathrm{~kg}$ sample. No particular correlation is visible between presence/absence of asteroid aggregations and concentrations of remains of other animals (e.g. bivalves, which asteroids are typically preying upon).

Ophiuroidea (11\%, 1362 specimens). Remains of ophiuroids are scattered throughout the entire succession except for samples Gns24-29 of section B. The largest numbers were counted in samples Gns4, Gns12, Gns13 and Gns36 with 135, 112, 211 and 114 specimens respectively. On average there are 36 ophiuroid specimens per $1 \mathrm{~kg}$ of sediment (Text-fig. 3).

Echinoidea (28\%, 3375 ossicles). Echinoids are the second most common group of echinoderms in the Gnaszyn section. Although their remains are generally quite evenly 
ECHINODERMS FROM MIDDLE JURASSIC ORE-BEARING CLAYS
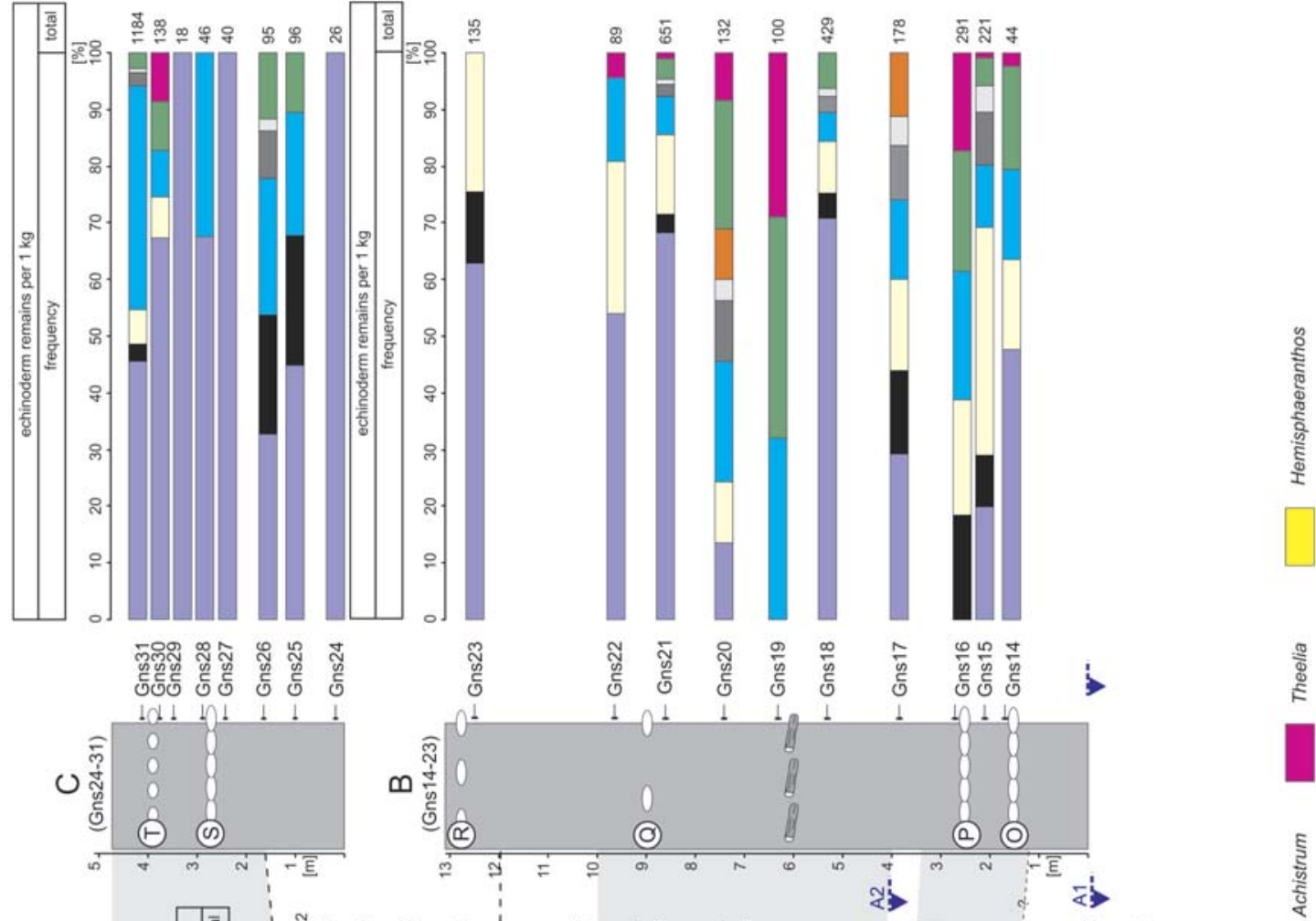

है
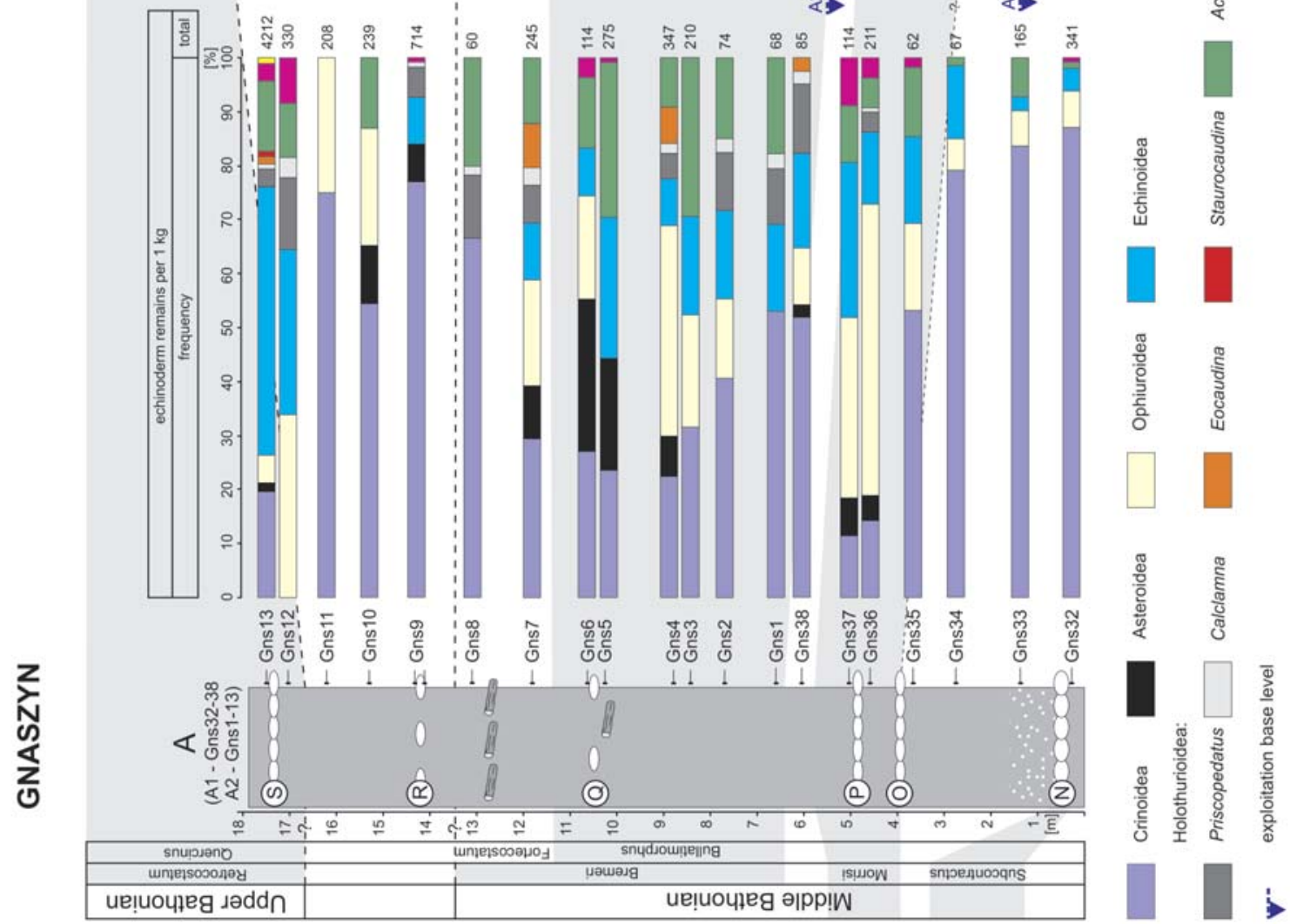

Text-fig. 3. Proportions of remains of various groups of echinoderms from the Bathonian ore-bearing clays of Gnaszyn (Czestochowa region), Poland. Letters in circles mark siderite concretion horizons. The other symbols as in Text-fig. 2 


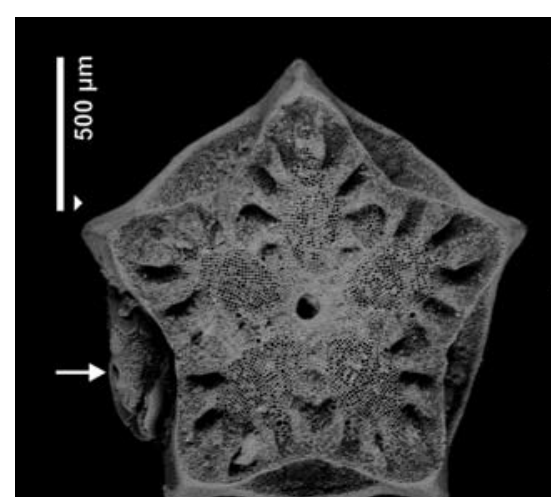

A1

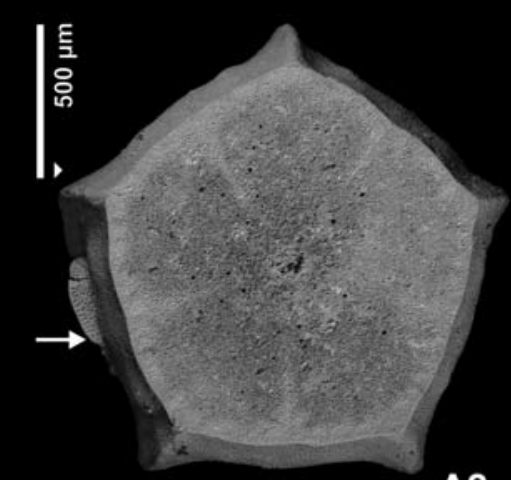

A2

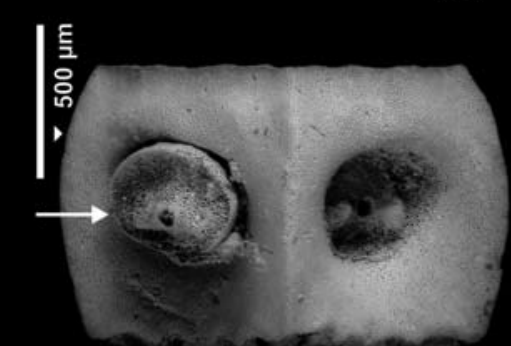

A3

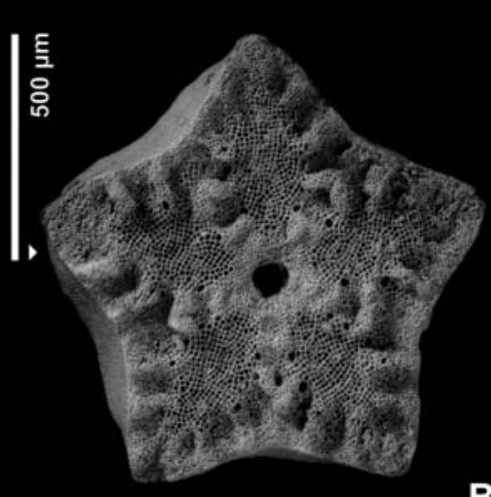

B

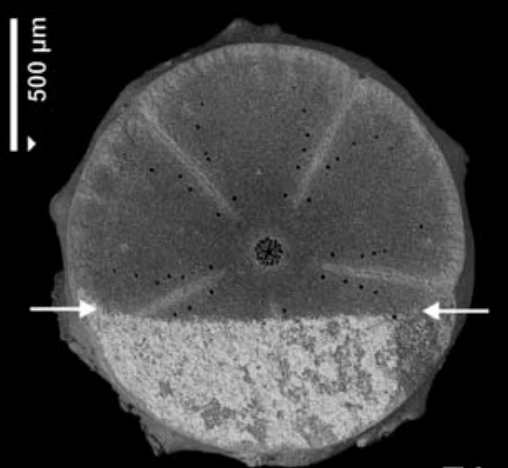

E1

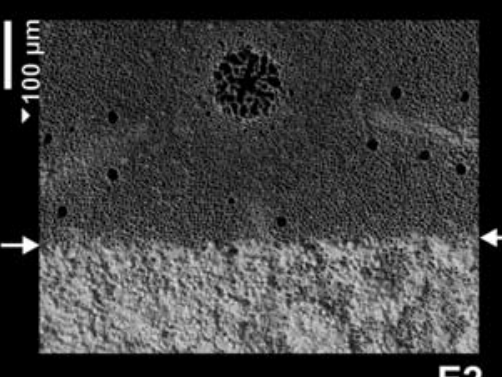

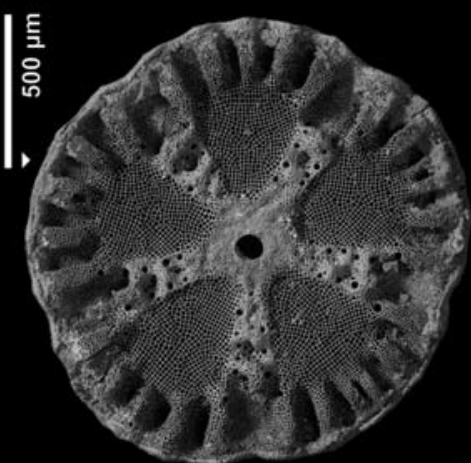

C

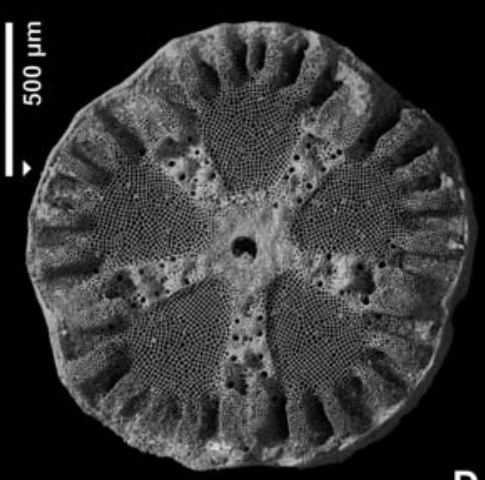

D

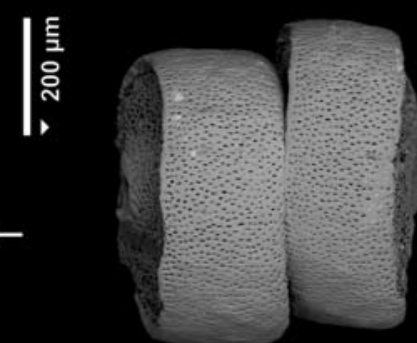

E2

$\mathbf{F}$

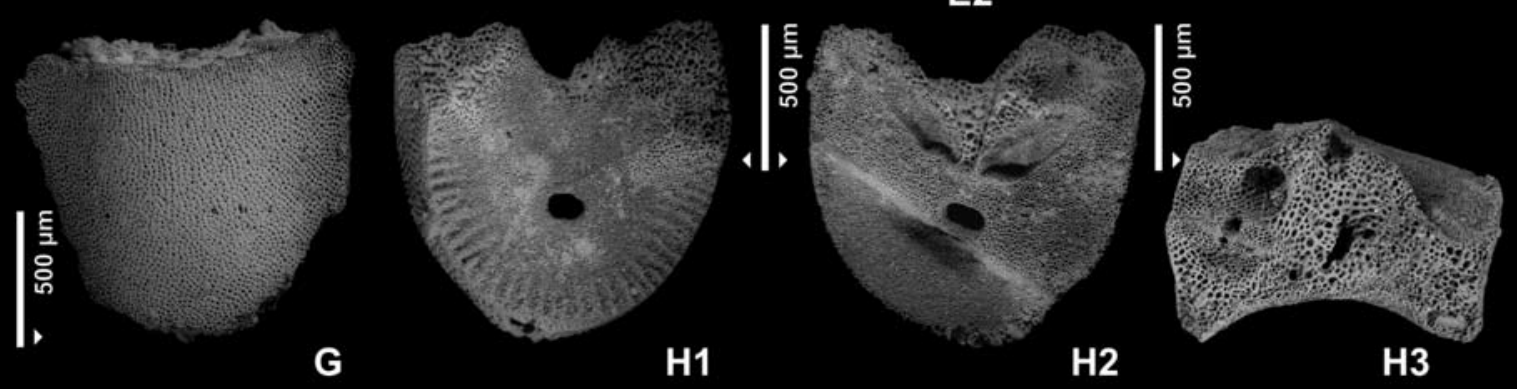

Text-fig. 4. Crinoid remains from the Bathonian ore-bearing clays of Gnaszyn (Częstochowa region), Poland. A - Chariocrinus andreae (Desor, 1845), nodal from the proxistele, arrow indicate proximal cirrals still attached to cirrus socket, sample Gns09, GIUS 8-2467 Gna. P09-CR-103. A1 - view of proximal articular facet; A2 - view of distal articular facet; A3 - side view. B - Chariocrinus cf. andreae (Desor, 1845), internodal from the proxistele, articular facet view, sample Gns31, GIUS 8-2489 Gna. P31-CR-104. C-D: Balanocrinus berchteni Hess and Pugin, 1983. C - internodal from the mesistele, articular facet view, sample Gns06, GIUS 8-2464 Gna. P06-CR-102. D - opposite internodal of previous one, articular facet view, sample Gns06, GIUS 8-2464 Gna. P06-CR-103. E - Balanocrinus sp. internodal from the mesistele, arrows indicate border between calcification and pyritization zone, sample Gns06, GIUS 8-2464 Gna. P06-CR-101. E1 - view of proximal articular facet; E2 - the same, details. F - proximal pluricirral, side view, sample Gns13, GIUS 8-2471 Gna. P13-CR-503. G-H: Some crinoid calyx elements from the Bathonian ore-bearing clays of Gnaszyn (Częstochowa region), Poland. G - basal plate, side view, sample Gns31, GIUS 8-2489 Gna. P31-CR-103. H - brachial plate, sample Gns13, GIUS 8-2471 Gna. P13-CR-522: H1 - H2 - brachial facet; H3 - inner view 


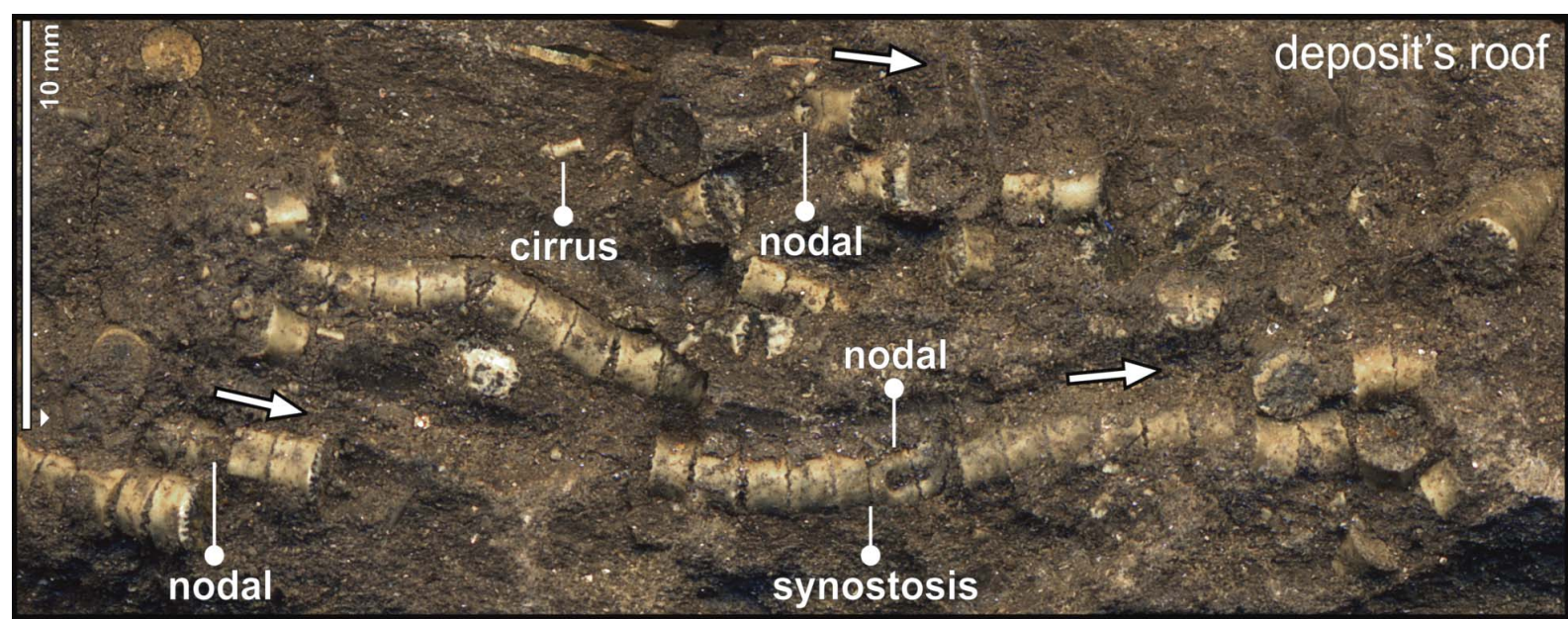

A

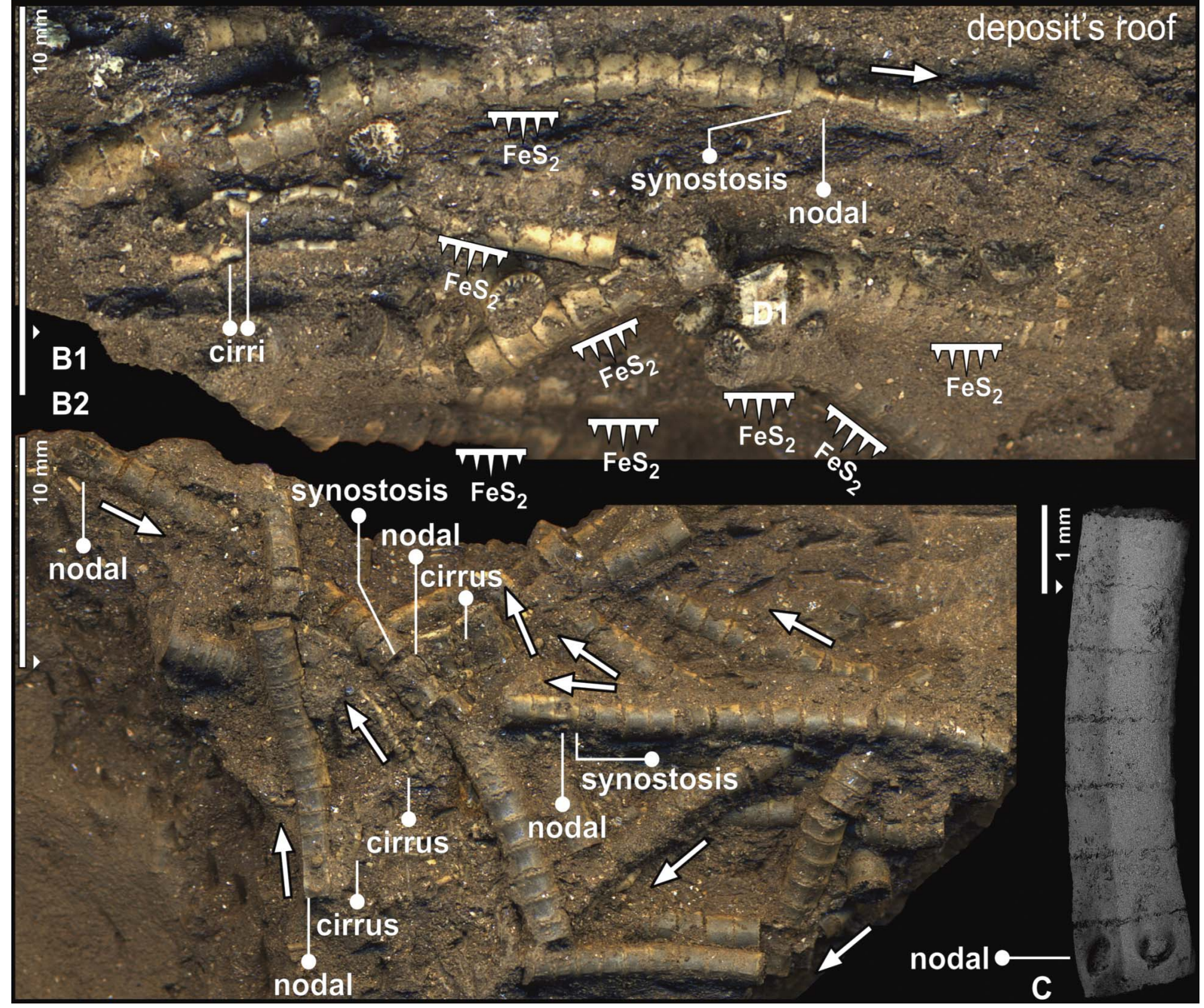

Text-fig. 5. Balanocrinus berchteni Hess and Pugin, 1983 from the Bathonian ore-bearing clays of Gnaszyn (Częstochowa region), Poland. Arrows indicate proximal direction of the stems. The majority of specimens are arranged in one direction, lie horizontally and commonly parallel. Cirri are situated near the stems. Cirrals are often arranged in anatomical position. A - stalks, bed section view. Sample Gns6, GIUS 8-2464 Gna. P06-CR-007. B - stalks, sample Gns6, GIUS 8-2464 Gna. P06-CR-005. B1 - bed section view, pyritization exists on the bottom of specimens only. B2 - floor bed view, all specimens are pyritized from this side. 


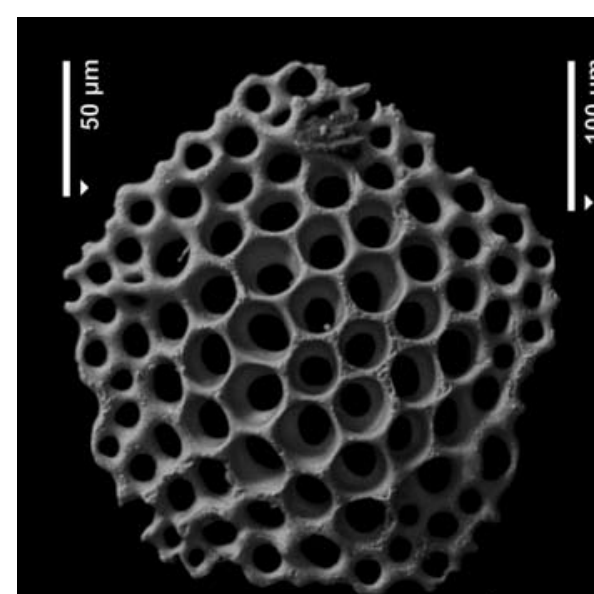

A

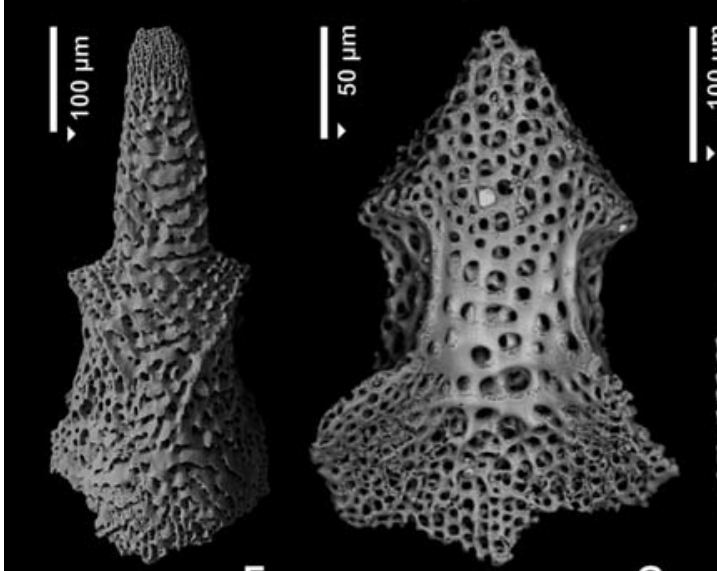

$\mathbf{F}$

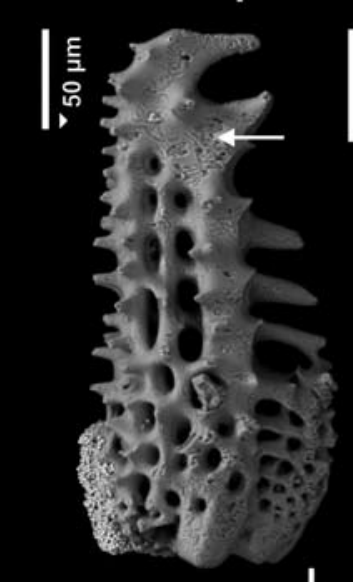

L

M

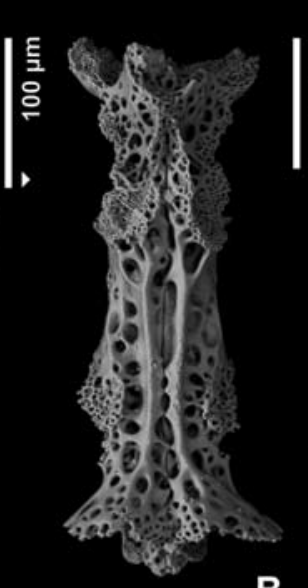

B

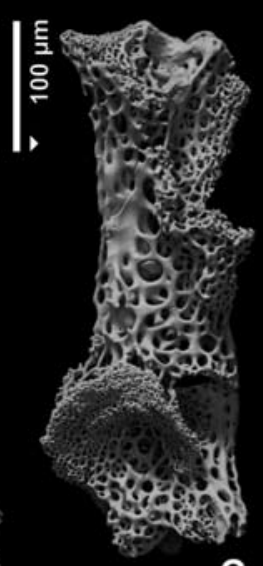

C

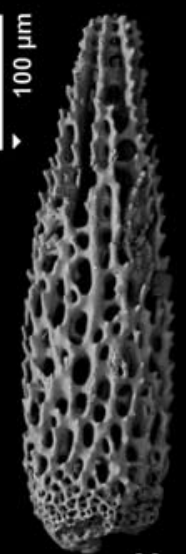

H

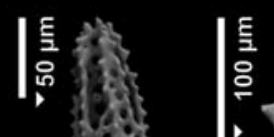

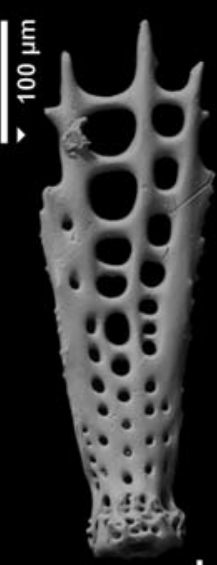

D

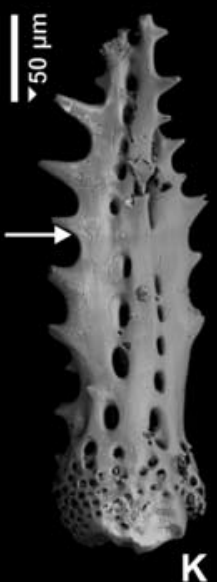

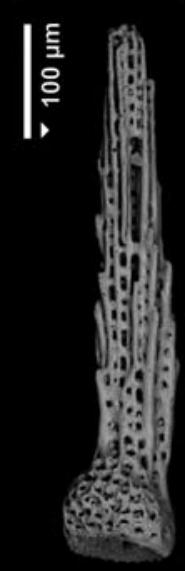
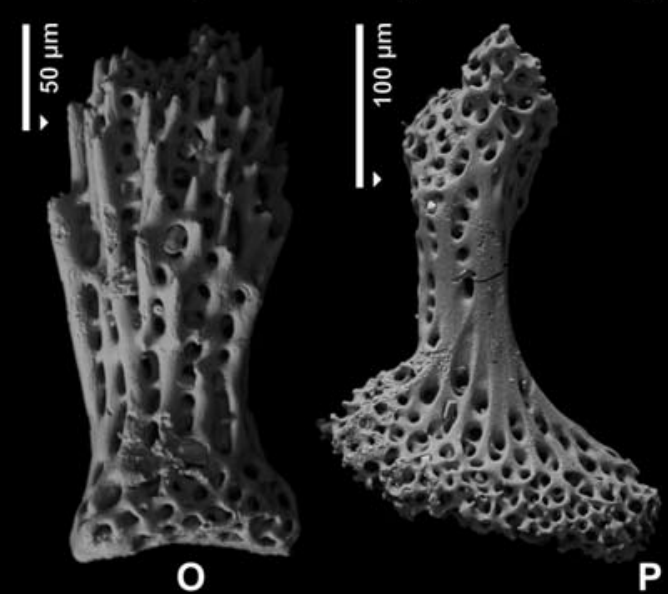

Text-fig. 6. Asterozoan skeletal elements, from the sample Gns13, Bathonian ore-bearing clays of Gnaszyn (Częstochowa region), Poland. Arrows indicate the traces of bacterial activity which took place during the decomposition of the echinoderm remains. A-M: skeletal elements of Ophiuroidea. A-centrodorsale from disc, outer view of the small specimen, GIUS 8-2471 Gna. P13-O-346. B - distal vertebra, dorsal view, GIUS 8-2471 Gna. P13-O-453. C - distal vertebra, lateral view, GIUS 82471 Gna. P13-O-323. D - distal lateral plate, inner view, GIUS 8-2471 Gna. P13-O-442. E - distal lateral plate, outer view, GIUS 8-2471 Gna. P13-O-441. F - distal ventral plate, outer view, GIUS 8-2471 Gna. P13-O-356. G - median ventral plate, inner view, GIUS 8-2471 Gna. P13-O-483. H - long arm thorny spine, side view, GIUS 8-2471 Gna. P13-O-459. I - short, flat arm thorny spine, side view, GIUS 8-2471 Gna. P13-O-451. J - arm scale, side view, GIUS 8-2471 Gna. P13-O-328. $\mathrm{K}$ - flat form intermediate between arm spine and arm hook, side view, morphotype 1, GIUS 8-2471 Gna. P13-O-457. L - form intermediate between arm spine and arm hook, side view, morphotype 2, GIUS 8-2471 Gna. P13-O-428. M - arm hook, side view GIUS 8-2471 Gna. P13-O-426. N - P: skeletal elements of Asteroidea. $\mathrm{N}$ - long spine, side view, GIUS 8-2471 Gna. P13-A-489. O - short spine, side view, GIUS 8-2471 Gna. P13-A-354. P- GIUS 8-2471 Gna. P13-A-360 


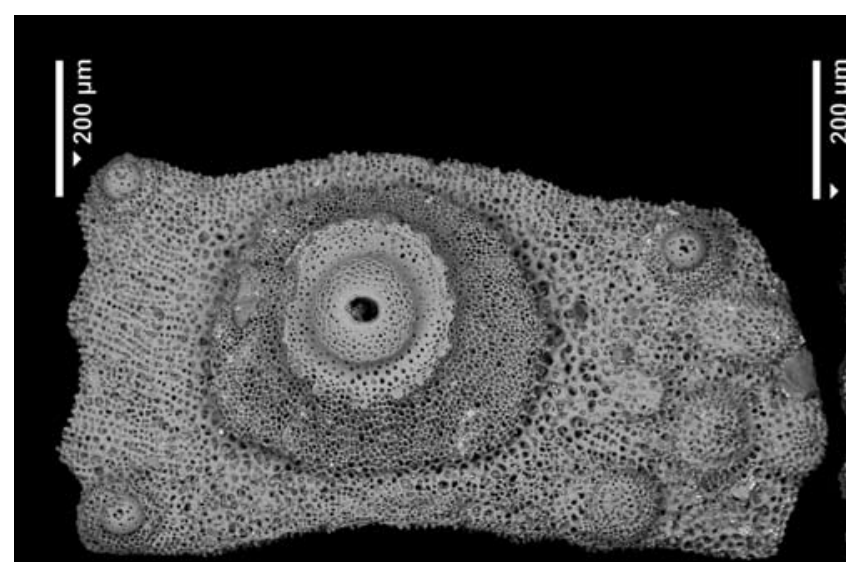

A
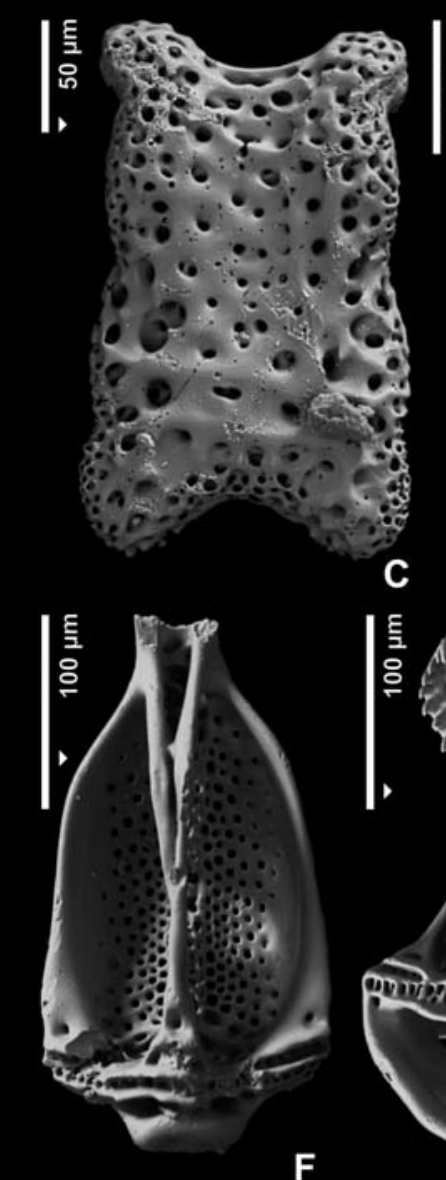

F
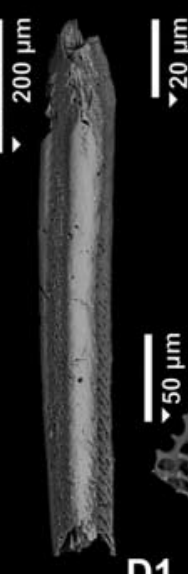

D1
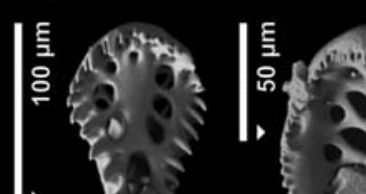

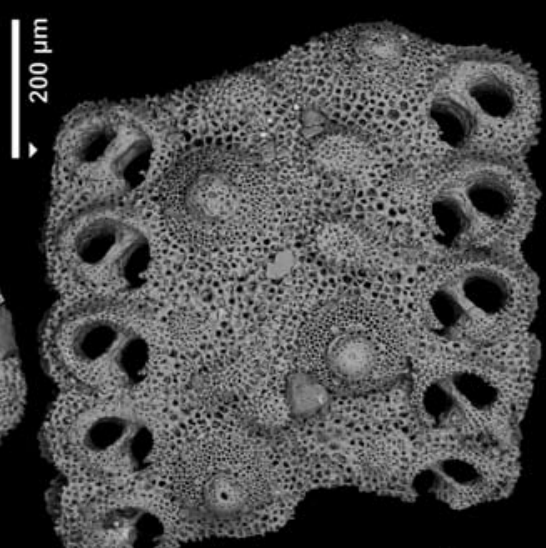

B

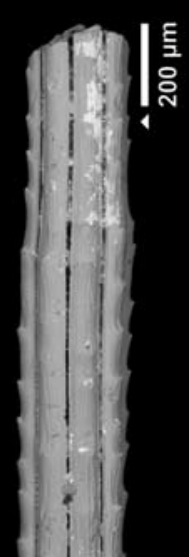

을
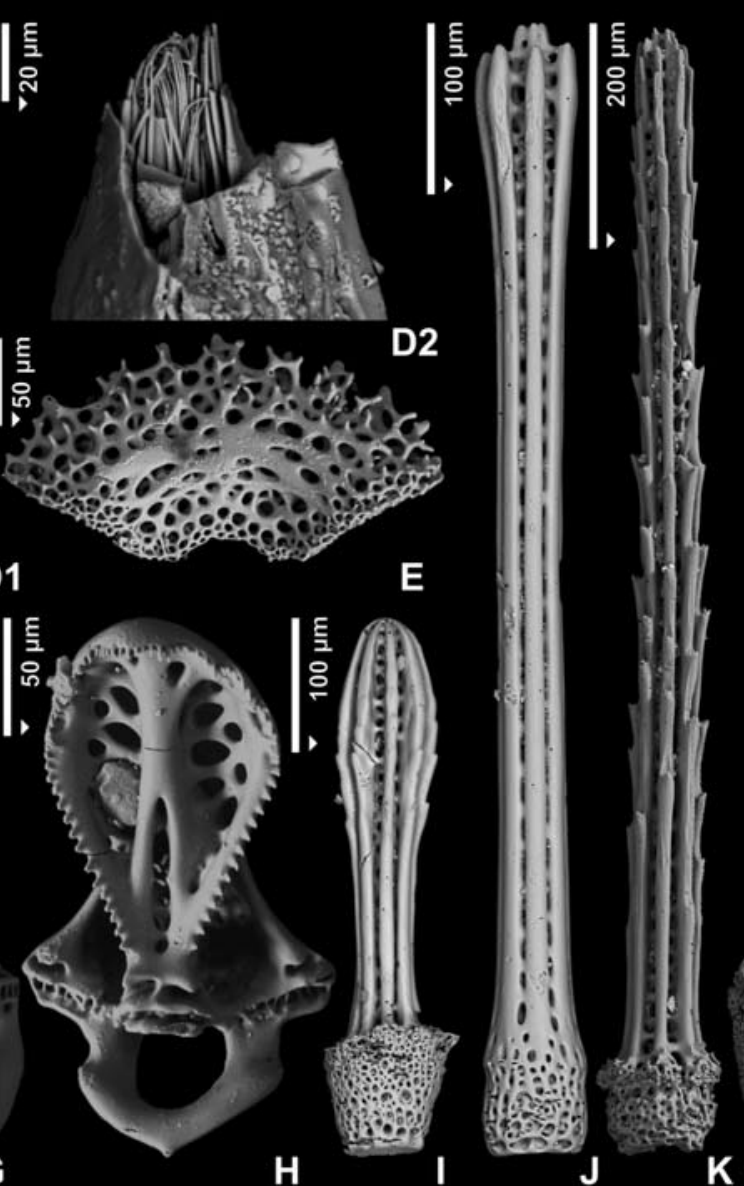

L

Text-fig. 7. Skeletal elements of Echinoidea from the sample Gns13, Bathonian, ore-bearing clay of Gnaszyn (Częstochowa region), Poland. A - interambulacral plate, outer view, GIUS 8-2471 Gna. P13-E-505. B - ambulacral plate, outer view, GIUS 8-2471 Gna. P13-E-506. C - rotula, apical surface, GIUS 8-2471 Gna. P13-E-450. D - tooth, adaxial view, GIUS 8-2471 Gna. P13-E-495. D1 - whole specimen; D2 - the same, apical tip. E - plate from sucking disc of tube foot, outer view, GIUS 8-2471 Gna. P13-E-464. F - globiferous pedicellaria with broken blade, adaxial view, GIUS 8-2471 Gna. P13-E-420. G - ophicephalous pedicellaria, morphotype II, adaxial view, GIUS 8-2471 Gna. P13-E-410. H - ophicephalous pedicellaria, morphotype III, adaxial view, GIUS 8-2471 Gna. P13-E-401. I - secondary spine, side view, GIUS 8-2471 Gna. P13-E-490. J - stem spicule of some pedicellaria, side view, GIUS 8-2471 Gna. P13-E-485. K-short primary spine, morphotype I, GIUS 8-2471 Gna. P13-E-472. L - long primary spine, morphotype II, GIUS 8-2471 Gna. P13-E-498 


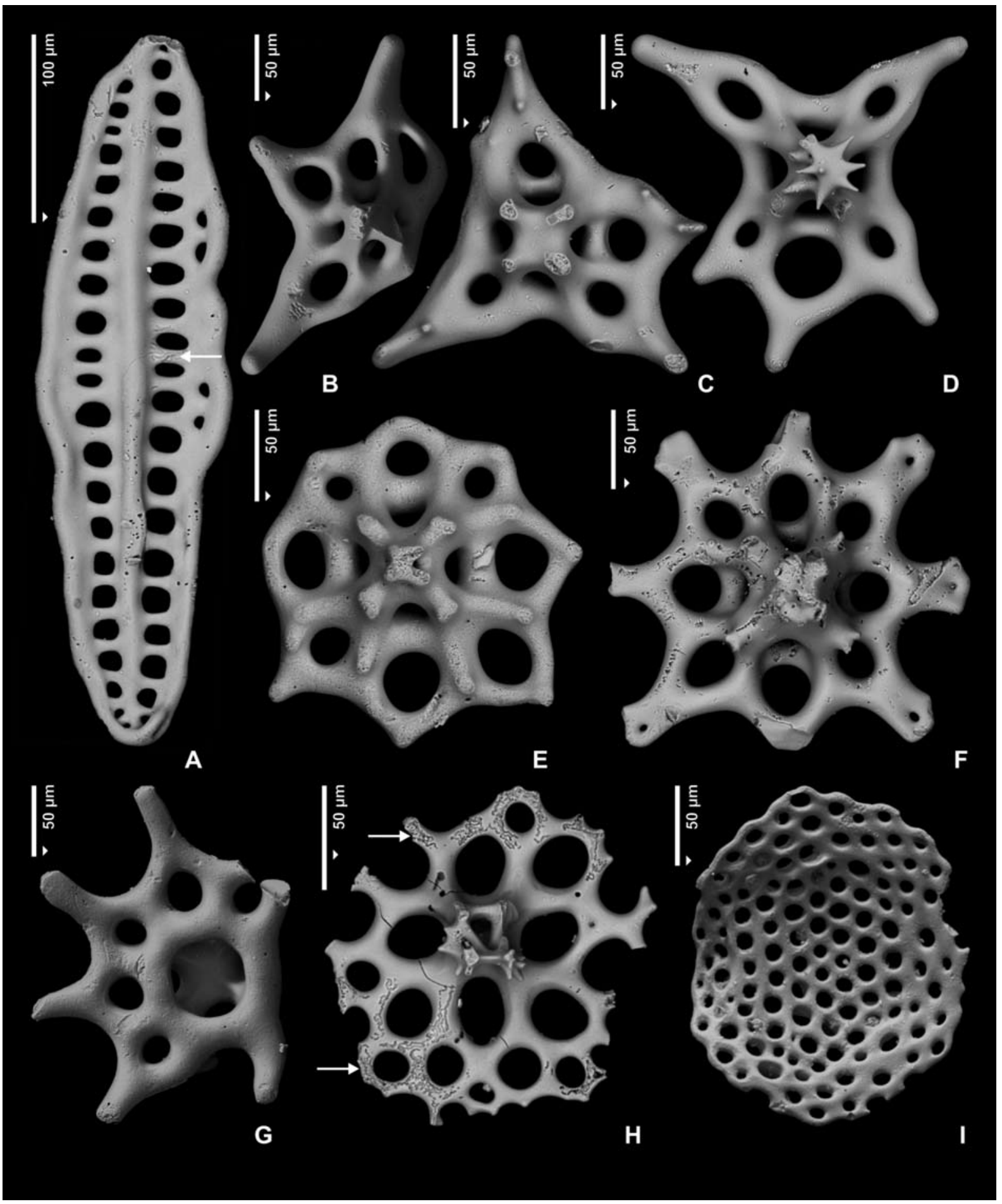

Text-fig. 8. Sclerites of Holothuroidea from the sample Gns13, Bathonian ore-bearing clays of Gnaszyn (Częstochowa region), Poland. Arrows indicate the traces of bacterial activity which took place during the decomposition of the echinoderm remains. A-Calclamnella sp. (sensu D.L. Frizzell and H. Exline 1956), side view, GIUS 8-2471 Gna. P13-H-516. B - Priscopedatus batoniensis Górka and Łuszczewska, 1969, dorsal side view, GIUS 8-2471 Gna. P13-H-334. C - Priscopedatus denticulatus Górka and Łuszczewska, 1969, dorsal side view, GIUS 8-2471 Gna. P13-H-510. D - Priscopedatus pentaradiatus Górka and Łuszczewska, 1969, dorsal side view, GIUS 8-2471 Gna. P13-H-515. E - Priscopedatus jaworznicensis Górka and Łuszczewska, 1969, dorsal side view, GIUS 8-2471 Gna. P13-H-509. F - Priscopedatus jaworznicensis Górka and Łuszczewska, 1969, dorsal side view, GIUS 8-2471 Gna. P13-H-512. G - Priscopedatus jaworznicensis Górka and Łuszczewska, 1969, ventral side view, GIUS 8-2471 Gna. P13-H-335. H - Priscopedatus sp., dorsal side view, GIUS 8-2471 Gna. P13-H-517. I - Eocaudina sp., 


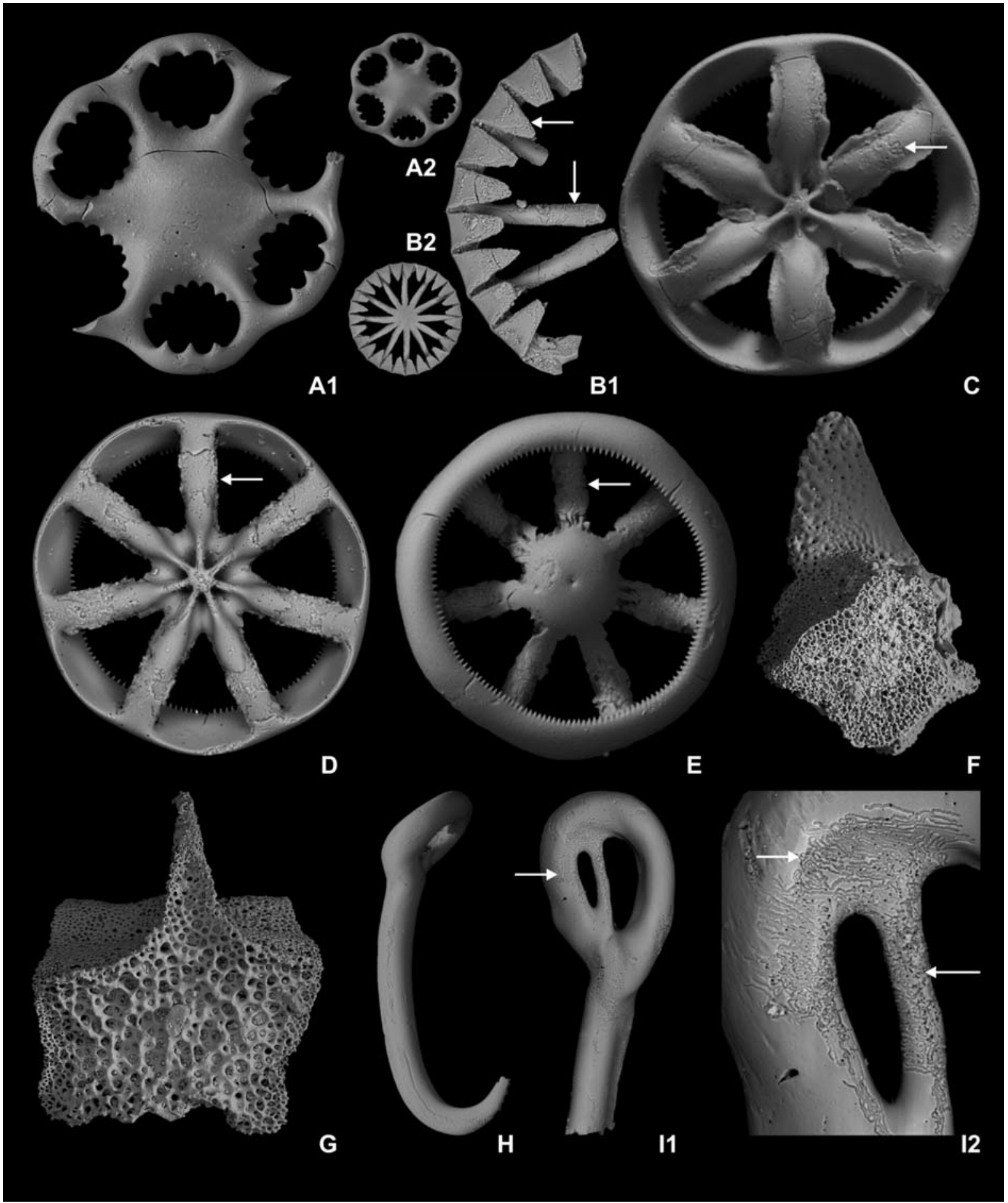

Text-fig. 9. Skeletal elements of Holothuroidea from the Bathonian ore-bearing clays of Gnaszyn (Częstochowa region), Poland. Arrows indicate the traces of bacterial activity which took place during the decomposition of the echinoderm remains. A - Staurocaudina sp., ventral view, sample Gns13, GIUS 8-2471 Gna. P13H-422. A1 - incomplete specimen; A2 - digital restoration of whole specimen, not to scale. B - Hemisphaeranthos malmensis (Frizzell and Exline, 1955), sample Gns13, GIUS 8-2471 Gna. P13-H-520. B1 - incomplete specimen; B2 - digital restoration of whole specimen, not to scale. C - Theelia dentata Górka and Łuszczewska, 1969, sample Gns13, GIUS 8-2471 Gna. P13-H-345, ventral view. D - E: Theelia heptalampra (Bartenstein, 1936) emend. Frizzell and Exline, 1955, complete specimens. D - ventral view, GIUS 8-2471 Gna. P13-H-519; E - dorsal view, GIUS 8-2471 Gna. P13-H-344. G - I: scleritome of Achistrum Etheridge, 1881 type. F - G: interradial plates from the calcareous ring. F - lateral view, sample Gns30, GIUS 8-1555 Gna. P03KN-H-307. G - outer view, sample Gns16, GIUS 8-1554 Gna. P02KN-H-304. H - I: hooks of Achistrum monochordata Hodson, Harris and Lawson, 1956. H - whole specimen, side view, sample Gns30, GIUS 8-1555 Gna. P03KN-H-309. I - incomplete specimen, GIUS 8-2471 Gna. P13-H-479. I1 - view on the eye; I2 - the same, details 
scattered in the succession ( 89 ossicles per $1 \mathrm{~kg}$ on average), their highest numbers were noted in samples Gns 13 and Gns31, with 2100 and 468 ossicles respectively. Echinoids occur commonly in "nests", which similarly as in the case of asteroids, may represent regurgitate of an echinoid predator. In one fifth of the samples no remains of echinoids were found (Text-fig. 3).

Holothuroidea $(18.7 \%$, 2257, 60 ossicles per $1 \mathrm{~kg}$ ). Sea cucumber sclerites are the third most common group of fossil echinoderms in the Gnaszyn section. They are also the most taxonomically diverse echinoderm group in Gnaszyn. Taking into account the fact that a single animal may consist, on average, of several millions of different skeletal elements, the relatively small numbers of holothurian sclerites points to a rather scattered occurrence of these animals in the Bathonian sea. The representatives of Achistrum Etheridge, 1881 and Theelia Schlumberger, 1890 are common throughout the section in Gnaszyn, while elements of Hemisphaeranthos Terquem and Berthelin, 1875 have been found only in sample Gns13. Theelia seems to be particularly common in levels close to siderite concretionary horizons (Text-fig. 3).

\section{PALAEOENVIRONMENTAL RECONSTRUCTIONS BASED ON ECHINODERM ASSEMBLAGES}

The majority of fossil echinoderms were motile benthic forms, except for crinoids which usually are sessile sestonophages (though crinoids occuring in Gnaszyn, i.e., isocrinids might be motile especially when endangered by predation; Baumiller et al. 2008) forming often large monospecific assemblages, the so-called crinoid meadows. Asteroids are motile benthic detritivores or solitary macrophages preying upon bivalves and other animals, including crinoids (e.g., Bowden et al. 2011; Eléaume et al. 2011). Ophiuroids are motile benthic detritivores or filter/suspension feeders often forming large monospecific communities. Some forms could be active predators. Echinoids belong to motile benthos, which consume the organic mats and films scraped off from the surface of underwater objects using their Aristotle's lantern, and crumble algae and organic detritus from the sea bottom. Some echinoids consume crinoids in a manner resembling eating spaghetti (Baumiller et al. 2010). Echinoderms may live either solitary or in groups. Holothurians are motile benthic animals, frequently forming large monospecific or polyspecific communities where they lead a sluggish mode of life. They can be rake-feeders, conveyor belt-feeders, filter-feeders and infaunal sedimentivores.
All these features make echinoderms a good tool for palaeoenvironmental reconstructions of bottom environments. Below, a concise characteristic of basic environmental parameters based on echinoderms is provided.

Salinity and water temperature. The presence of diverse and ubiquitous echinoderms throughout the Gnaszyn succession points to fully-marine bottom water conditions. No evidence for any drop in salinity of the bottom waters is detected, based on echinoderm frequency. The low diversity of the echinoderms, especially the Holothuroidea, in Gnaszyn may be related to water temperature. A low species variability of Holothuroidea is typical of cold and temperate water zones. Monospecific assemblages, usually with high abundances, occur in both cold and temperate climate zones, as well as in cold waters of the oceanic depths. Holothuroidea from warm-water environments commonly appear in taxonomically rich assemblages, but characterized by low specimen numbers. The echinoderms from Gnaszyn indicate rather temperate or cool bottom water conditions.

Sedimentation rate and oxygen content. Generally the crinoid skeletal elements in Gnaszyn are dispersed in the sediment as isolated ossicles, but some skeletal elements are still articulated. This especially concerns the crinoid stems preserved horizontally to the bedding (Text-fig. 5). Such specimens were found in samples collected from levels of siderite concretion horizons, especially in the higher part of the Gnaszyn succession (samples Gns6, Gns9, Gns13, Gns28; see Text-fig. 3). The longest pluricolumnal found in the exposure was $16 \mathrm{~cm}$ long. The crinoid stems occur occasionally in bunches with particular stems close to each other, quite often in contact. Most stems within one cluster were oriented in one direction, while different clusters of crinoid stems were oriented in various directions. These clusters of crinoid remains were narrow and at least $1 \mathrm{~m}$ long. Crinoid stems formed characteristic entangled strings composed of numerous individuals lying almost parallel to each other (Text-fig. 5). The layers containing such clusters of crinoids did not exceed $20 \mathrm{~mm}$ in thickness. Apart from such clusters, larger skeletal aggregates of crinoids are rare.

The taphonomy of those crinoid remains suggests that these animals could have been attached to the bottom and that, after death, the whole community fell to the bottom and the entire aggregate became submerged in the soft sediment (Hess et al. 1999). Some of the stems were disarticulated when the specimens were falling to the bottom. Those crinoids could have 
formed string clusters lying on the bottom and attached to submarine objects with their cirri. Such a mode of settling stabilised many individuals on the muddy sea bottom. Thus, the presence of echinoderm remains that are still in anatomical contact suggests relatively high rates of sedimentation (although it might be assumed that even a thin layer of clay was enough to cover and protect the microscopic and delicate sclerites, which in Gnaszyn quite commonly remain in anatomic contact). High sedimentation rates are particularly suggested in that the dead bodies of echinoderms usually become decomposed within a very short time (from a few days in tropical waters to more than four weeks in cold water in temperature about $11^{\circ} \mathrm{C}$; Kidwell and Baumiller 1990). On the other hand, the sedimentation rate in Gnaszyn must have been slow enough to enable epibionts to colonize the exposed echinoderms remains. Numerous small epibiontic sedentary polychaetes and bryozoans have been observed in Gnaszyn on echinoid remains and, less commonly, on crinoids or asteroids (all samples). The occurrence of these epibionts suggests that the echinoderm remains were exposed on the sediment surface for a significant period. Epibionts are also very often found on pieces of mollusc shells (Zatoń and Taylor 2010).

The articulated skeletons of crinoids also suggest a quiet environment with no strong bottom currents. Decomposed echinoderms consist of such tiny particles that even a weak bottom current could scatter the remains on the bottom and cause their disarticulation. This feature suggests that the strata which host the concretion horizons were deposited in a quieter environment than the remaining parts of the Gnaszyn succession.

Another indirect indication of sedimentation rate may be the common occurrence of holothurians, a group which is usually associated with the presence of plant remains. Detritus-feeding holothurians feed on decomposing plant material or on epiphytic organisms associated with plants or organisms feeding on plants. Thus, the common occurrence of holothurians among the echinoderms from Gnaszyn may be interpreted as resulting from sufficient amounts of the plant detritus that served as the main food source for these animals.

Despite a relatively high rate of sedimentation, associated with a high influx of organic remains into the bottom environment, the aerobic conditions at the bottom of the Gnaszyn sea must have remained good enough for benthic echinoderm life, such as the numerous ophiuroids, which die quickly when the oxygen balance is disturbed (Hyman 1955). Those ophi- uroids, which live partly buried in the sediment, have the ends of their arms protruded above the sediment, which enables them to breathe.

Thus, aerobic bottom water conditions in Gnaszyn, optimal for echinoderms, are indisputable. However, the oxic conditions at the water/sediment interface seem to have changed into an oxygen-depleted environment in the underlying sediment. Many of the echinoderm remains, which were only partially buried in the bottom sediment, have pyritized bottom sides, whereas their upper parts, not buried immediately after death, are pale coloured, with no traces of pyritization (Textfig. 4E). The pyritization of the parts submerged in sediment must have occurred at a very early stage, before complete burial of the skeleton in the sediment. This phenomenon is well known from contemporary sea bottoms, where pyritization occurs immediately under anaerobic conditions (Deming et al. 1997; Glass 2006). Moreover, numerous echinoderm sclerites from Gnaszyn are covered by characteristic micro-traces (Text-figs 6K, L; 8A, H; 9C-E, H, I), from 1.5 to 2.0 $\mu \mathrm{m}$ in width and up to $200 \mu \mathrm{m}$ in length. Compact meandering traces form dense clusters, especially in the hollows of sclerites. Irregular traces usually cover one side of a fossil only. Linear, deep traces can form large, grid-like clusters. These traces reflect anaerobic bacterial activity (see Boczarowski 2005a for details), which took place under anaerobic conditions after burial of the echinoderm remains. The slow process of decomposition of organic material continuously lowered the $\mathrm{pH}$ values in the sediment, enhancing anaerobic/dysaerobic conditions around the decaying carcass. Analysis of the frequency of particular microtrace types on the echinoderm ossicles in Gnaszyn showed that the most densely bioeroded were sclerites of infaunal and semiinfaunal echinoderms. When these animals died buried in the sediment they decomposed under anaerobic conditions. On the other hand, no bacterial microtraces have been observed on the remains of echinoderm groups obviously belonging to epifauna (crinoids, sea stars, and regular echinoids; Boczarowski 2005a). All the above-mentioned observations also suggest that the sediment/water interface was a boundary between relatively well-oxygenated bottom waters and an oxygen-depleted substratum. The latter environment was optimal for the growth of pyrite (see Witkowska et al. 2004).

\section{CONCLUDING REMARKS}

Echinoderm remains are common throughout the Gnaszyn succession. These animals lived on a soft 
bottom, in water of normal salinity. The generally low taxonomic richness indicates temperate or even cool bottom water conditions. Only the echinoderm assemblage from sample Gns13 displays a considerable increase in both abundance and taxonomic richness. This exceptional composition reflects specific palaeoenvironmental conditions particularly favourable for echinoderms. However, the nature of these conditions is uncertain; it may have resulted from several different environmental and sedimentological features.

Usually echinoderm carcasses disaggregate rapidly due to decomposition and the energy of the environment. In Gnaszyn, when echinoderm remains were found articulated, they usually consist of two skeleton pieces (samples Gns5, Gns6, Gns9, Gns12, Gns13, Gns15, Gns16, Gns21, Gns23, Gns27, Gns28, Gns30, Gns31, Gns32, Gns35, Gns36, Gns37). However, there are some levels associated with concretion horizons (samples Gns6, Gns9, Gns13, Gns28) where crinoid stems remain articulated (Text-fig. 5), suggesting a quiet environment and low levels of bioturbation.

The taxonomic richness of the echinoderm assemblages increases in levels of siderite concretion horizons as well as at horizons with sunken wood trunks (especially above such horizons, samples Gns5, Gns6, Gns9, Gns12, Gns13, Gns14, Gns15, Gns16, Gns19, Gns21, Gns30, Gns31, Gns36, Gns37). This phenomenon is apparently caused by the availability of hard bottom surfaces for attachment in these layers. It seems that periods of concretion layer formation were characterized by a lower sedimentation rate and better oxygenation. The low sedimentation rate may have also facilitated prolonged exposure of organic remains on the sea bottom. This might have been responsible for the ubiquitous occurrence of Theelia (samples Gns12, Gns13, Gns16, Gns19) and echinoid sclerites (samples Gns3, Gns5, Gns9, Gns12, Gns13, Gns15, Gns16, Gns19, Gns21, Gns22, Gns31, Gns36, Gns37) in these levels.

Some post-depositional features of the echinoderm remains (traces of pyritization and anaerobic bacterial activity) suggest oxygen-depleted conditions in the sediment. The value of oxidative-reductive potential Eh must have been within the limit of $0.2 \mathrm{~V}$ in subsurface layers of the ore-bearing clays (Boczarowski 2005a), promoting the activity of anaerobic bacteria. Thus, the sediment/water interface in Gnaszyn was also a boundary between well oxygenated bottom waters appropriate for the development of benthic communities, and anaerobic/dysaerobic conditions in the substratum.

\section{Acknowledgements}

The constructive criticism of Aaron W. Hunter (London, U.K.), Mike Reich (Göttingen, Germany) and two anonymous referees are highly appreciated. Extensive improvements by guest editors Przemysław Gedl (Kraków, Poland) and Andrzej Kaim (Warszawa, Poland) are kindly acknowledged.

\section{REFERENCES}

Baumiller, T.K., Mooi, R. and Messing, C.G. 2008. Urchins in a meadow: paleobiologial and evolutionary implications of cidaroid predation on crinoids. Paleobiology, 34, 22-34.

Baumiller, T.K., Salamon, M., Gorzelak, P., Mooi, R., Messing, C. and Gahn, F. 2010. Post-Paleozoic crinoid radiation in response to benthic predation preceded the Mesozoic marine revolution. Proceedings of the National Academy of Sciences of the United States of America, 107, 58935896.

Boczarowski, A. 2001. Isolated sclerites of Devonian nonpelamtozoan echinoderms. Palaeontologia Polonica, 59, $1-219$.

Boczarowski, A. 2004. Pedicellariae from Middle Jurassic Ore Bearing Częstochowa Clay Formation and their significance in echinoid's life strategy. Tomy Jurajskie, 2, 141-150.

Boczarowski, A. 2005a. Znaczenie gnilnych mikrośladów zachowanych na sklerotomach szkarłupni $\mathrm{z}$ batonu Gnaszyna. Tomy Jurajskie, 3, 132-135.

Boczarowski, A. 2005b. Chromo-stereoscopy as a tool in micropalaeontological investigations: echinoderms as a case study. Studia Geologica Polonica, 124, 21-35.

Bowden, D.A., Schiaparelli, S., Clark, M.R. and Rickard, G.J. 2011. A lost world? Archaic crinoid dominated assemblages on an Antarctic seamount. Deep Sea Research Part II: Topical Studies in Oceanography, 58, 119-127.

Dayczak-Calikowska, K. 1980. Crinoidea. In: L. Malinowska (Ed.), Budowa geologiczna Polski, Vol. 3, Atlas skamieniałości przewodnich i charakterystycznych, część 2b (Mezozoik, Jura), p. 249. Wydawnictwa Geologiczne, Warszawa.

Deming, J.W., Reysenbach, A.-L., Macko, S.A. and Smith, C.R. 1997. Evidence for the microbial basis of a chemoautotrophic invertebrate community at a whale fall on the deep seafloor: bone-colonizing bacteria and invertebrate endosymbionts. Microscopy Research and Technique, 37, 162-170.

Eléaume, M., Hemery, L.G., Bowden, D.A. and Roux, D.A. 2011. A large new species of the genus Ptilocrinus (Echinodermata, Crinoidea, Hyocrinidae) from Antarctic seamounts. Polar Biology, 34, 1385-1397.

Frizzell, D.L. and Exline, H. 1956. Monograph of Fossil Holothurian Sclerites. Bulletin of School of Mines and Metallurgy (Technical Series), 89 (for 1955), 1-204. 
Gedl, P. and Kaim, A. 2012. An introduction to alaeoenvironmental reconstruction of Bathonian (Middle Jurassic) orebearing clays at Gnaszyn, Kraków-Silesia Monocline, Poland. Acta Geologica Polonica, 62 (3), 267-280.

Gedl, P., Kaim, A., Boczarowski, A., Kędzierski, M., Smoleń, J., Szczepanik, P., Witkowska, M., and Ziaja, J. 2003. Rekonstrukcja paleośrodowiska sedymentacji środkowojurajskich iłów rudonośnych Gnaszyna (Częstochowa) wyniki wstępne. Tomy Jurajskie, 1, 19-27.

Gedl, P., Kaim, A., Boczarowski, A., Dudek, T., Kędzierski, M., Leonowicz, P., Sawłowicz, Z., Smoleń, J., Szczepanik, P., Witkowska, M., and Ziaja, J. 2004. Rekonstrukcja paleośrodowiska sedymentacji środkowojurajskich iłów rudonośnych Gnaszyna (Częstochowa). Tomy Jurajskie, $2,166$.

Glass, A. 2006. Pyritised tube feet in a protasterid ophiuroid from the Upper Ordovician of Kentucky, U.S.A. Acta Palaeontologica Polonica, 51, 171-184.

Górka, H., and Łuszczewska, L. 1969. Holothurian sclerites from the Polish Jurassic and Tertiary. Annales de la Sociéte Géologique de Pologne, 39, 361-402.

Hess, H., Ausich, W.I., Brett, C.E. and Simms, M.J. 1999. Fossil Crinoids, pp. 1-275. Cambridge University Press; Cambridge. Hyman, L.H. 1955. The Invertebrates: Echinodermata, pp. vii + 763. McGraw-Hill; New York, Toronto, London.

Jesionek-Szymańska, W. 1963. Echinides irreguliers du Dogger de Pologne. Acta Palaeontologica Polonica, 8 (3), 293-414.

Jesionek-Szymańska, W. 1980. Echinoidea. In: L. Malinowska (Ed.), Budowa geologiczna Polski, Vol. 3, Atlas skamieniałości przewodnich i charakterystycznych, część $2 b$ (Mezozoik, Jura), pp. 249-253. Wydawnictwa Geologiczne; Warszawa.

Kidwell, S.M. and Baumiller, T. 1990. Experimental Disintegration of Regular Echinoids: Roles of Temperature, Oxygen, and Decay Thresholds. Paleobiology, 16, 247-271.

Laube, G.C. 1867. Die Echinodermen des braunen Jura von Balin. Mit Berücksichtigung ihrer geognostischen Verbreitung in Frankreich, Schwaben, England und anderen Ländern. Denkschrift der Kaiserlichen Akademie der Wissenschaften in Wien, Mathematisch-Naturwissenschaftliche Klasse, 27, 1-10.

Ludwig, H. 1889-92. Echinodermen. 1. Die Holothurien. In: Bronn's Their-Reich, 2 (3), 1-460.

Majewski, W. 2000. Middle Jurassic concretions from Częstochowa (Poland) as indicators of sedimentation rates. Acta Geologica Polonica, 50, 431-439.

Matyja, B.A. and Wierzbowski A. 2003. Biostratygrafia amonitowa formacji częstochowskich iłów rudonośnych (najwyższy bajos-górny baton) z odsłonięć w Częstochowie. Tomy Jurajskie, 1, 3-6.

Matyja, B.A. and Wierzbowski, A. 2006. European Platform -
Middle and Upper Jurassic, In: Wierzbowski, A., Aubrecht, R., Golonka, J., Gutowski, J., Krobicki, M., Mstyjs, B.A., Pieńkowski, G. and Uchman, A. (Eds), Jurassic of Poland and adjacent Slovakian Carpathians. Field trip guidebook of 7 th International Congress on the Jurassic System Poland, Kraków, September 6-18, 2006, 130-132.

Mays, T.D., Holdeman, L.V., Moore, W.E.C., Rogosa, M. and Johnson, J.L. 1982. Taxonomy of the genus Veillonella Prévot. International Journal of Systematic Bacteriology, 32, 28-36.

Mosher, C. 1980. Distribution of Holothuria arenicola Semper in the Bahamas with observations on habitat, behavior and fiding activity (Echinodermata: Holothuroidea). Bulletin of Marine Science, 30, 1-12.

Price, A.R.G. 2007. Western Arabian Gulf Echinoderms in high salinity waters and the occurrence of dwarfism. A Journal of Natural History, 16, 1464-5262.

Rehbinder, B. 1913. Die mitteljurassischen eisenerzführenden Tone längs des südwestlichen Randes des KrakauWieluner Zuges in Polen. Zeitschrift der Deutschen Geologischen Gesselschaft, 65, 181-349.

Różycki, S.Z. 1953. Górny dogger i dolny malm jury krakowsko-częstochowskiej. Prace Instytutu Geologicznego, 17, 1-412.

Salamon, M.A., 2008. Jurassic cyrtocrinids (Cyrtocrinida, Crinoidea) from extra-Carpathian Poland. Palaeontographica, Abt. A, 285, 77-99.

Salamon, M.A. and Zaton, M. 2006. Balanocrinus hessi n. sp., a new crinoid (Echinodermata) from the Callovian (Middle Jurassic) of southern Poland. Neues Jahrbuch für Geologie und Paläontologie, Abhandlungen, 240, 1-17.

Salamon, M.A. and Zatoń, M. 2007. Late Bajocian through Callovian (Middle Jurassic) crinoid fauna from the epicontinental deposits of Poland. Swiss Journal of Geosciences, 100, 153-164.

Stolarski, J., Gorzelak, P., Mazur, M., Marrocchi, Y. and Meibom, A. 2009. Nanostructural and geochemical features of the Jurassic isocrinid columnal ossicles. Acta Palaeontologica Polonica, 54, 69-75.

Thomas, L.P. 1961. Distribution and salinity tolerance in the amphiurid brittlestar, Ophiophragmus filograneus (Lyrnan, 1875). Bulletin of Marine Science of the Gulf and Caribbean, 11, 158-160.

Witkowska, M., Szczepanik, P. and Sawłowicz, Z. 2004. Rekonstrukcja paleośrodowiska sedymentacji środkowojurajskich iłów rudonośnych Gnaszyna (Jura KrakowskoCzęstochowa) w świetle badań geochemicznych. Tomy Jurajskie, 2, 166-167.

Zatoń, M. and Taylor, P.D. 2010. Bathonian (Middle Jurassic) cyclostome bryozoans from the Polish Jura. Bulletin of Geosciences, 85, 275-302.

Zaton, M., Salamon, M.A., Marynowski, L. and Zatoń, R. 2007a. Nest-like accumulations of faunal remains in the 
Middle Jurassic ore-bearing clays of the Kraków-Częstochowa Upland and their palaeobiological implications. Przeglad Geologiczny, 55, 424-429.
Zaton, M., Villier, L. and Salamon, M.A. 2007b. Signs of predation in the Middle Jurassic of south-central Poland: evidence from echinoderm taphonomy. Lethaia, 40, 139-151.

Manuscript submitted: 01 ${ }^{\text {st }}$ August 2010

Revised version accepted: $31^{\text {st }}$ August 2012 